Article

\title{
Improving Growth, Yield, and Quality of Tomato Plants (Solanum lycopersicum L.) by the Application of Moroccan Seaweed-Based Biostimulants under Greenhouse Conditions
}

\author{
Abir Mzibra ${ }^{1,2, *}$, Abderrahim Aasfar ${ }^{1}$, Mehdi Khouloud ${ }^{3}$, Youssef Farrie ${ }^{3}$, Rachid Boulif ${ }^{3}$, \\ Issam Meftah Kadmiri 1,4,*D, Ahmed Bamouh ${ }^{2}$ and Allal Douira ${ }^{5}$ \\ 1 Laboratory of Green Biotechnology, Moroccan Foundation for Advanced Science, Innovation and \\ Research (MAScIR), Rabat Design Center, Rue Mohamed Al Jazouli, Madinate Al Irfane, \\ Rabat 10100, Morocco; a.aasfar@mascir.com \\ 2 Production, Protection et Biotechnologie Végétales, Institut Agronomique et Vétérinaire Hassan II (IAV HII), \\ BP 6446, Madinate Al Irfane, Rabat 10100, Morocco; a.bamouh@iav.ac.ma \\ 3 OCP Group Jorf Lasfar, R\&D Center, Mohammed VI Polytechnic University, El Jadida 24000, Morocco; \\ Mehdi.KHOULOUD@um6p.ma (M.K.); Youssef.FARRIE@ocpgroup.ma (Y.F.); rachid.boulif@um6p.ma (R.B.) \\ 4 Plant and Soil Microbiome Sub-Program, Biodiversity and Plant Sciences, AgroBioSciences, \\ Mohammed VI Polytechnic University, Ben Guerir 43150, Morocco \\ 5 Laboratory of Botany and Plant Protection, Faculty of Sciences, Ibn Tofail University, Kenitra 14000, Morocco; \\ douiraallal@hotmail.com \\ * Correspondence: abiir.mzi@gmail.com (A.M.); i.kadmiri@mascir.com (I.M.K.)
}

Citation: Mzibra, A.; Aasfar, A.; Khouloud, M.; Farrie, Y.; Boulif, R.; Kadmiri, I.M.; Bamouh, A.; Douira, A Improving Growth, Yield, and Quality of Tomato Plants (Solanum lycopersicum L.) by the Application of Moroccan Seaweed-Based Biostimulants under Greenhouse Conditions. Agronomy 2021, 11, 1373. https://doi.org/ 10.3390/agronomy11071373

Received: 26 May 2021

Accepted: 2 July 2021

Published: 6 July 2021

Publisher's Note: MDPI stays neutra with regard to jurisdictional claims in published maps and institutional affiliations.

Copyright: (c) 2021 by the authors. Licensee MDPI, Basel, Switzerland. This article is an open access article distributed under the terms and conditions of the Creative Commons Attribution (CC BY) license (https:// creativecommons.org/licenses/by/ $4.0 /)$
Abstract: Background: Seaweed-derived extracts have gained popularity in agriculture as bioproducts with phytostimulatory effects on plant growth and development. Methods: This study assessed the effect of polysaccharide-enriched extracts (PEEs) derived from six Moroccan seaweeds on tomato growth, yield, and fruit quality. PPEs were applied to tomato plants as soil drench in a greenhouse experiment. Growth parameters including plant height $(\mathrm{cm})$ and number of leaves, flowers, and flower buds were recorded every 15 days. Yield and quality parameters of the harvested fruits were also recorded after each harvest. Results: The obtained results showed that all PEEs improved the growth, yield, and fruit quality of treated tomato plants. According to principal component analysis, the presence of $\mathrm{SO}_{4}$, galactose, glucose, and maltose in the characterized polysaccharides was closely associated with their effect on plant growth, yield, and fruit quality parameters. Conclusions: PEEs obtained from Gelidium crinale, Schizymenia dubyi, Fucus spiralis, and Bifurcaria bifurcata exhibited the highest biostimulant effects and could be used as bioproducts for improved tomato yield and fruit nutritional quality.

Keywords: agronomic assays; tomato; PEEs; seaweeds; quality; yield

\section{Introduction}

High crop production is required to feed the ever-growing global population, which is projected to reach 10 billion by 2050. More than half of this population increase is expected to occur in Africa, adding approximately 1.3 billion more people to the continent $[1,2]$. Improving crop quality is another big challenge for modern farmers since consumers are increasingly interested in products with high organoleptic, nutritional, and functional attributes [3-5]. To achieve reasonable yields and high-quality products, producers use excessive doses of chemical fertilizers and a wide range of pesticides that could have adverse damage on the ecology of agricultural systems, leading to chemical contamination of soils, water supplies, and harvested products [6,7]. Thus, improving crop quality and yield without negatively affecting the environment remains a big challenge.

For several years, the positive effects of natural bioactive formulations such as biostimulants have been widely reported. Such bioproducts support the pro-ecological cultivation 
of vegetables and fruits [8,9]. Biostimulants are products derived from organic materials containing bioactive substances and/or microorganisms that have the capacity to improve crop performance. These products, applied directly to plants or to the soil (rhizosphere), stimulate several physiological and molecular processes that lead to increased nutrient uptake and use efficiency, enhanced tolerance to abiotic stresses, and crop yield and quality $[8,10-12]$.

The use of seaweed extract formulations as plant biostimulants is well documented and has increased in recent years. Biostimulants have negligible nutrient concentrations and act on plant metabolism [13]. They can be applied as fertilizer additives to enhance nutrient uptake and use efficiency and improve plant growth, yield, crop quality, and tolerance to abiotic stresses [14-21]. Extracts derived from seaweeds contain biochemical compounds, including polysaccharides, proteins, polyunsaturated fatty acids, pigments, polyphenols, minerals, and plant growth hormones [12]. Some studies have reported that high molecular weight molecules such as polysaccharides and polyphenols extracted from marine seaweeds can act as biostimulants to improve crop yield and quality. Alginate oligosaccharides obtained from sodium alginate significantly enhanced the overall yield of crude opium per plant [22]. Carrageenan, the algal polysaccharides extracted from red seaweeds, exerts spectacular effects on physiological activities leading to enhanced crop productivity $[23,24]$. Maningas et al. (2016) reported that carrageenan increased rice yield by up to $60 \%$ [25].

Tomato (Solanum lycopersicum L.) is one of the most popular and widely consumed vegetable crops in the world, with a production of $182 \mathrm{MT}$ per year [26]. Tomato production is a source of income for many rural and peri-urban producers in several developing countries [27,28]. In Morocco, tomato is cultivated on more than 15,888 ha, producing nearly 1.29 MT in 2017 and taking 17th place in the world [26,29]. Tomato fruits have recently gained popularity in relation to human disease prevention due to the presence of carotenoids and particularly lycopene. Lycopene is an unsaturated alkylic compound and powerful antioxidant that play an important role in the prevention of prostate cancer and reducing the risks of cardiovascular diseases through their ability to modulate disease process pathways [30,31]. Tomato quality depends on a combination of different quality attributes such as appearance (color, size, and shape), flavor (total soluble solids, sugar, and organic acid), nutritional value (lycopene, vitamin C, minerals), and storage qualities [32].

The present study is the continuation of the previously published research work on enhancing tomato plant growth through the application of polysaccharide-enriched extracts (PEEs) obtained from 17 Moroccan seaweed species. Different concentrations and two application methods were tested on germination and growth parameters of tomato plants [33]. From the 17 polysaccharides, eight polysaccharides with their application dose and method were selected for the production of effective biostimulants of early tomato seed germination and plant growth. Such bioproducts reduce the use of synthetic compounds and provide an eco-friendly approach to plant nutrient management for sustainable agriculture. In light of the above limited reviews and results, the present work aimed to evaluate the effect of six Moroccan polysaccharides screened from the previous studies [33,34] as biostimulants of the vegetative and reproductive growth of tomato plants and subsequent yield and organoleptic quality of harvested fruits.

\section{Materials and Methods}

\subsection{Preparation of Polysaccharide-Enriched Extracts (PEEs)}

Six polysaccharide-enriched extracts (PEEs) were obtained from different seaweed species collected from the Moroccan littoral in August 2016 (Table 1). The studied seaweed species included two green seaweeds (Ulva rigida and Codium tomentosum), two red seaweeds (Gelidium crinale and Schizymenia dubyi), and two brown seaweeds (Fucus spiralis and Bifurcaria bifurcata). Polysaccharides were extracted by the conventional hot water method under neutral conditions followed by polysaccharide precipitation using ethanol. Mzibra et al. (2020) [33] previously described the details of the extraction method. PEEs 
were characterized for their total sugars, reducing sugars and protein and sulfate contents [34].

Table 1. Collection site locations of the 6 studied seaweeds.

\begin{tabular}{cccc}
\hline Seaweed & Location & GPS Point & Date of Collection \\
\hline Chlorophyta & & & 3 August 2016 \\
\hline Ulva rigida & Ouled Hmimoun-Mohammedia & $33^{\circ} 40^{\prime} 34^{\prime \prime} \mathrm{N}, 7^{\circ} 26^{\prime} 55^{\prime \prime} \mathrm{W}$ & 3 August 2016 \\
\hline Codium tomentosum & Guy Ville-El Harhoura & $33^{\circ} 56^{\prime} 11^{\prime \prime} \mathrm{N}, 6^{\circ} 56^{\prime} 45^{\prime \prime} \mathrm{W}$ & \\
\hline Rhodophyta & & & 17 August 2016 \\
\hline Gelidium crinale & El Jadida beach & $33^{\circ} 14^{\prime} 564^{\prime \prime} \mathrm{N}, 8^{\circ} 29^{\prime} 41^{\prime \prime} \mathrm{W}$ & 3 August 2016 \\
\hline Schizymenia dubyi & Ain Sebaa-Casablanca & $33^{\circ} 37^{\prime} 14^{\prime \prime} \mathrm{N}, 7^{\circ} 32^{\prime} 9^{\prime \prime} \mathrm{W}$ & \\
\hline Phaeophyta & & & 17 August 2016 \\
\hline Fucus spiralis & Sidi Daoui & $33^{\circ} 15^{\prime} 3511^{\prime \prime} \mathrm{N}, 8^{\circ} 30^{\prime} 875^{\prime \prime} \mathrm{W}$ & $33^{\circ} 13^{\prime} 2952^{\prime \prime} \mathrm{N}, 8^{\circ} 33^{\prime} 19^{\prime \prime} \mathrm{W}$ \\
\hline Bifurcaria bifurcata & Sidi Bouzid & 17 August 2016 \\
\hline
\end{tabular}

\subsection{Plant Material and Experimental Design}

Agronomic trials were conducted in the experimental greenhouse of Ibn Tofail University of Kenitra (Morocco) between January and May of 2019 to determine the effect of seaweed polysaccharide-enriched extracts (PEEs) on the growth, yield, and quality of tomato plants. Tomato seeds (Solanum lycopersicum L., JANA F1) were surface sterilized and sown in a depth of $1.5 \mathrm{~cm}$ on seedling trays filled with $25 \mathrm{~g}$ of peat moss. The trays were placed in a phytotron growth chamber at $26^{\circ} \mathrm{C}, 16: 8 \mathrm{~h}$ photoperiod, and $240 \mu \mathrm{mol} \mathrm{m}{ }^{-2} \mathrm{~s}^{-1}$ luminosity at the Green Biotechnology laboratory of the Moroccan Foundation for Advanced Sciences, Innovation and Research (MAScIR). After 4 weeks, uniform germinated seedlings (4-5 mature leaves) were transported to the experimental greenhouse and transplanted into pots of $5 \mathrm{~L}$ containing $5 \mathrm{~kg}$ of sterilized mixture of peat moss and sand $(2: 2 \mathrm{v} / \mathrm{v})$. Pots were placed in a randomized complete block experimental design. Each treatment consisted of 15 replicates (three plants per pot). Plants were adequately watered with tap water and fertilized when needed with a nutritive solution (Steiner 60\%) (Table 2).

Table 2. Chemical composition of the nutrient solution (Steiner 60\%) applied to tomato plants during the test.

\begin{tabular}{cc}
\hline Fertilizing Elements & Quantity in Grams Mixed with 30 L of Water \\
\hline Ammonitrate & 17.9 \\
Potassium sulfate $(\mathrm{SOP}) \mathrm{K}_{2} \mathrm{SO}_{4}$ & 21.4 \\
Monoammonium phosphate $(\mathrm{MAP}) \mathrm{NH}_{4} \mathrm{H}_{2} \mathrm{PO}_{4}$ & 5.55 \\
Calcium nitrate $\mathrm{Ca}\left(\mathrm{NO}_{3}\right)_{2}$ & 28.9 \\
Magnesium sulfate $\mathrm{MgSO}_{4}$ & 15.21 \\
Mixture of chelated trace elements & 1.7 \\
Iron (Fe) & 2 \\
\hline
\end{tabular}

\subsection{Treatments Application}

The six liquid PEEs formulations were prepared at the Green Biotechnology laboratory of MAScIR. Extracts were mixed with distilled water to achieve different concentrations, then autoclaved $\left(121^{\circ} \mathrm{C}\right.$ for $15 \mathrm{~min}$ ) and transported to the experimental greenhouse for plant treatments. Based on the optimal extract concentrations previously established when screening seaweed polysaccharide-enriched extracts [33,34], the PEEs derived from $U$. rigida, $C$. tomentosum, and B. bifurcata were prepared at $0.1 \mathrm{mg} \cdot \mathrm{mL}^{-1}$ and PEEs derived from G. crinale, F. spiralis, and S. dubyi were prepared at $0.02 \mathrm{mg} \cdot \mathrm{mL}^{-1}$. The first PEEs treatment was applied $24 \mathrm{~h}$ after transplantation. Then two applications at intervals of 15 days each were carried out during the vegetative growth phase and one last application 
during the reproduction phase. For each application, $300 \mathrm{~mL}$ PEE was applied to each pot (100 mL per plant). Control plants were treated with an equal volume of distilled water.

\subsection{Agronomic Measurements}

\subsubsection{Growth Parameters}

To observe the dynamic changes in plant growth, the following growth parameters were recorded every 15 days: plant height $(\mathrm{cm})$ measured from the cotyledons to extreme growing tip using a meter scale, number of leaves (recorded until the leaf pruning stage), number of flowers and number of flower buds.

Pruning consists of removing old leaves, basal leaves touching the ground, diseased leaves as well as leaves under the floral bouquet. It was carried out 90 days after transplantation and 20 days before the harvest stage in order to accelerate the ripening of the fruits, facilitate harvesting, and also ensure suitable aeration, sunstroke, and better ventilation between the plants.

\subsubsection{Yield Parameters}

Harvesting of fruits started at 115 days after transplantation; fruits were handpicked every week from April to May as they gradually achieved physiological maturity. After each harvest, fruits were immediately transferred to MAScIR laboratory, and yield parameters were recorded as: number of fruits per plant, fresh weight of harvested fruits per plant $(\mathrm{g})$, and the equatorial diameter of each fruit $(\mathrm{cm})$.

\subsubsection{Quality Parameters}

After each harvest, a representative sample of uniform unblemished fruits having similar size and color from each experimental pot was chosen for the determination of fruit quality parameters:

- $\quad$ The total soluble solids (TSS) was determined according to the method described by Tigist et al. (2013) [35]. An aliquot of tomato juice was extracted using a juice extractor and filtered with a cheesecloth. TSS was determined by placing 1 to 2 drops of clear juice on the prism of a digital Pocket refractometer (ATAGO PAL- $\alpha$ Cat. No: 3840, Tokyo, Japan). Results were expressed in Brix degrees reflecting sugar concentration in the fruit. The prism of the refractometer was washed with distilled water and dried between samples;

- The titratable acidity (TTA), expressed as percentage citric acid, was determined according to the method described by Tigist et al. (2013) [35]. Tomato juice (10 mL) was manually titrated using $01 \mathrm{~N} \mathrm{NaOH}$ to an endpoint of $\mathrm{pH} 8.2$ using a digital $\mathrm{pH}$ meter (sensION TM + MM340, Barcelona, Spain). The titrated volume of $0.1 \mathrm{~N} \mathrm{NaOH}$ was recorded, and the acidity was calculated as a citric acid percentage (\% of juice) by using the following formula:

$$
\text { The Titrable acidity }(\%)=\frac{\text { volume of } \mathrm{NaOH}(\mathrm{mL}) \times \text { acid factor } \times 100}{\text { Volume of juice }(\mathrm{mL})}
$$

${ }^{*}$ Factor of citric acid $=0.0064$

- Sugar-acid ratio, also called maturity index, was calculated by dividing total soluble solid (TSS) to titratable acidity (TTA) of the given sample under analysis:

$$
\text { The sugar acid ratio }=\frac{\text { Brix value }}{\text { Percentage acid }}
$$

- $\quad$ Lycopene content was measured following the method described by Suwanaruang (2016) [36]. Fresh fruit samples (1 mg) were dissolved in $1 \mathrm{~mL}$ of distilled water and vortexed in a water bath at $30^{\circ} \mathrm{C}$ for $1 \mathrm{~h}$, then $8 \mathrm{~mL}$ of hexane: ethanol: acetone (2:1:1) was added. The samples were capped and vortexed immediately, then incubated out of bright light. After $10 \mathrm{~min}, 1 \mathrm{~mL}$ water was added to each sample and vortexed 
again. Samples were allowed to stand for $10 \mathrm{~min}$ to allow phases to separate and all air bubbles to disappear. Then the absorbance of samples was determined at $503 \mathrm{~nm}$ by spectrophotometry. The concentration of lycopene was calculated using the extinction coefficient:

$$
\text { Lycopene }(\mathrm{mg} / \mathrm{kg})=\text { Abs503nm } \times 537 \times 8 \times 0.55 / 0.10 \times 172
$$

\subsection{Statistical Analysis}

The obtained data were analyzed for significant differences using IBM SPSS statistics 23. One-way analysis of variance was carried out for each parameter studied to assess significant differences at the $5 \%$ level in treatments and their interaction for all parameters. Comparison of the treatment means was performed using Fisher's protected LSD.

Principal component analysis (PCA) of the correlation table obtained between variables including PEEs chemical composition (glucose, maltose, galactose, sulfate, and protein contents) and plant growth, yield, and fruit quality parameters was carried out using R software version 3.5, package: MixOmics, FactoMineR, Factoextra, and FactoMineR

\section{Results}

\subsection{Polysaccharides Characterization}

The lyophilized PEEs were characterized for their sulfate, protein, and carbohydrates (galactose, glucose, and maltose) content (Table 3).

Table 3. Chemical composition of the six seaweed species polysaccharide-enriched extracts (PEEs).

\begin{tabular}{cccccc}
\hline \multirow{2}{*}{$\begin{array}{c}\text { PEEs Seaweed } \\
\text { Samples }\end{array}$} & \multicolumn{3}{c}{ Total Carbohydrates \% } & \multirow{2}{*}{$\begin{array}{c}\text { Sulfate \% } \\
\text { (SO }\end{array}$} & Protein \% \\
\cline { 2 - 4 } & Glucose & Maltose & Galactose & & \\
\hline Ulva rigida & $22.91 \pm 4.67$ & $19.68 \pm 4.31$ & $29.48 \pm 5.61$ & $8.17 \pm 0.08$ & $0.05 \pm 0.00$ \\
Codium tomentosum & $37.2 \pm 6.1$ & $32.86 \pm 5.63$ & $46.65 \pm 7.33$ & $6.53 \pm 0.02$ & $0.34 \pm 0.02$ \\
Fucus spiralis & $23.22 \pm 4.44$ & $19.96 \pm 4.1$ & $29.85 \pm 5.34$ & $4.15 \pm 0.01$ & $0.04 \pm 0.04$ \\
Gelidium crinale & $44.42 \pm 2.9$ & $39.52 \pm 2.68$ & $55.34 \pm 3.49$ & $5.66 \pm 0.02$ & $0.02 \pm 0.02$ \\
Schizymenia dubyi & $21.15 \pm 5.25$ & $18.05 \pm 4.87$ & $27.36 \pm 6.31$ & $7.66 \pm 0.01$ & $0.02 \pm 0.02$ \\
Bifurcaria bifurcata & $34.09 \pm 0.49$ & $29.99 \pm 0.45$ & $42.91 \pm 0.59$ & $5.46 \pm 0.01$ & $0.29 \pm 0.00$ \\
\hline
\end{tabular}

\subsection{Effect of PPEs on Growth Parameters}

Cumulative data of vegetative growth parameters (stem length and number of leaves per plant) along with reproductive growth parameters (number of flowers and number of flower buds) are presented in Table 4. Measurements were recorded at 15, 30, 45, 60, 75, 90, and 105 days after transplantation (DAT) of tomato plants under the effect of different treatments of polysaccharide-enriched extracts (PEEs) obtained from marine seaweeds.

Length of stems was significantly higher in plants irrigated with PEEs compared to control plants from 15 DAT throughout the trial period. The number of leaves per plant increased significantly with PEEs treatments at 30, 60, and 75 DAT and exceptionally by $U$. rigida and C. tomentosum PEEs at 45 and 90 DAT compared to the control plants.

Reproductive growth represented by the number of flowers also increased significantly with the application of PEEs obtained from $U$. rigida and C. tomentosum at 45, 60, and 90 DAT and PEEs obtained from G. crinale, S. dubyi and B. bifurcata at 60 and 75 DAT (Table 4).

Fruit set stage started at 45 DAT in plants treated with PEEs obtained from F. spiralis and at 60 DAT in plants treated with PEEs obtained from U. rigida, C. tomentosum, G. crinale, S. dubyi, and B. bifurcata, compared with control plants that started the fruit set stage at 75 DAP. It can be clearly deduced that the PEEs treatments stimulated the precocity of fruit set in the tomato plants (Table 4). 


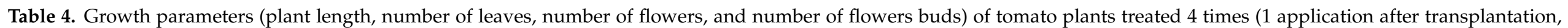

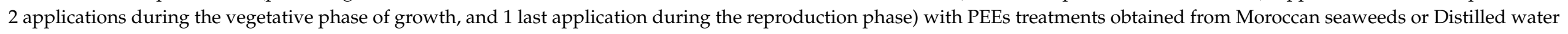
(control plants). The data represent the mean values of 15 repetitions \pm standard deviations. Different letters represent significant statistical values at $(p \leq 0.05)$.

\begin{tabular}{|c|c|c|c|c|c|c|c|c|}
\hline $\begin{array}{c}\text { Growth } \\
\text { Parameters }\end{array}$ & $\begin{array}{c}\text { Days after } \\
\text { Transplantation }\end{array}$ & Control & U. rigida & C. tomentosum & F. spiralis & G. crinale & S. dubyi & B. bifurcata \\
\hline \multirow{8}{*}{$\begin{array}{l}\text { Length of stems } \\
\qquad(\mathrm{cm})\end{array}$} & 0 & $5.97 \pm 0.62^{\mathrm{a}}$ & $5.97 \pm 0.77^{a}$ & $5.80 \pm 0.84^{\mathrm{a}}$ & $5.73 \pm 0.73^{a}$ & $6.13 \pm 0.83^{\mathrm{a}}$ & $5.61 \pm 0.75^{\mathrm{a}}$ & $5.70 \pm 0.73^{\mathrm{a}}$ \\
\hline & 15 & $10.99 \pm 1.18^{b}$ & $12.01 \pm 1.06^{\mathrm{a}}$ & $12.30 \pm 1.18^{a}$ & $12.61 \pm 1.35^{\mathrm{a}}$ & $12.72 \pm 1.24^{\mathrm{a}}$ & $12.45 \pm 1.15^{\mathrm{a}}$ & $12.51 \pm 0.83^{a}$ \\
\hline & 30 & $33.99 \pm 1.48^{c}$ & $40.25 \pm 2.96^{b}$ & $40.20 \pm 3.04^{b}$ & $42.13 \pm 2.30^{a}$ & $41.76 \pm 2.15^{\mathrm{a}}$ & $41.43 \pm 2.39^{a}$ & $42.08 \pm 1.93^{\mathrm{ab}}$ \\
\hline & 45 & $65.00 \pm 1.55^{\mathrm{d}}$ & $69.08 \pm 3.33^{c}$ & $70.59 \pm 3.15^{b c}$ & $72.85 \pm 2.19^{a}$ & $72.67 \pm 1.97^{\mathrm{a}}$ & $72.06 \pm 2.08^{a b}$ & $72.87 \pm 2.19^{a}$ \\
\hline & 60 & $73.00 \pm 1.9^{\mathrm{c}}$ & $77.65 \pm 2.98^{b}$ & $77.53 \pm 3.18^{b}$ & $82.06 \pm 2.29^{a}$ & $80.44 \pm 2.16^{\mathrm{a}}$ & $81.25 \pm 2.23^{a}$ & $81.70 \pm 2.1^{\mathrm{a}}$ \\
\hline & 75 & $80.03 \pm 2.64^{c}$ & $84.86 \pm 2.61^{b}$ & $84.49 \pm 2.85^{b}$ & $87.84 \pm 2.27^{\mathrm{a}}$ & $87.13 \pm 2.22^{a}$ & $87.33 \pm 2.31^{\mathrm{a}}$ & $87.47 \pm 1.97^{\mathrm{a}}$ \\
\hline & 90 & $85.73 \pm 3.04^{c}$ & $90.87 \pm 2.48^{b}$ & $91.33 \pm 2.79 \mathrm{ab}$ & $92.9 \pm 2.33^{\mathrm{a}}$ & $92.1 \pm 2.42^{\mathrm{a}}$ & $92.88 \pm 2.09^{a}$ & $92.94 \pm 2.12^{\mathrm{a}}$ \\
\hline & 105 & $89.13 \pm 2.72^{c}$ & $95.27 \pm 2.58^{b}$ & $96.10 \pm 2.53^{b}$ & $99.6 \pm 3.66^{\mathrm{a}}$ & $96.43 \pm 2.58^{b}$ & $97.14 \pm 2.34^{b}$ & $96.96 \pm 2.07^{b}$ \\
\hline \multirow{8}{*}{ Number of leaves } & 0 & $4.07 \pm 0.26^{\mathrm{a}}$ & $3.73 \pm 0.46^{b}$ & $4.13 \pm 0.35^{\mathrm{a}}$ & $4.00 \pm 0.38^{a b}$ & $4.20 \pm 0.41^{\mathrm{ab}}$ & $3.93 \pm 0.46^{\mathrm{ab}}$ & $4.07 \pm 0.26^{\mathrm{a}}$ \\
\hline & 15 & $5.87 \pm 0.35^{\mathrm{a}}$ & $6.13 \pm 0.35^{\mathrm{a}}$ & $6.13 \pm 0.35^{\mathrm{a}}$ & $6.13 \pm 0.52^{\mathrm{a}}$ & $6.33 \pm 0.62^{a}$ & $6.07 \pm 0.59^{a}$ & $6.13 \pm 0.52^{a}$ \\
\hline & 30 & $8.93 \pm 0.64^{c}$ & $10.27 \pm 1.16^{b}$ & $10.87 \pm 0.99 \mathrm{ab}$ & $11.00 \pm 0.93^{\mathrm{a}}$ & $11.4 \pm 0.99^{a}$ & $11.13 \pm 0.83^{\mathrm{a}}$ & $11.2 \pm 0.56^{\mathrm{a}}$ \\
\hline & 45 & $13.8 \pm 0.94^{b}$ & $14.67 \pm 1.05^{\mathrm{a}}$ & $14.47 \pm 0.99^{\mathrm{a}}$ & $14.27 \pm 0.88^{a b}$ & $13.87 \pm 0.74^{\mathrm{ab}}$ & $13.8 \pm 0.68^{b}$ & $14.13 \pm 0.92^{\mathrm{ab}}$ \\
\hline & 60 & $16.07 \pm 0.71^{c}$ & $17.67 \pm 1.05^{\mathrm{a}}$ & $17.33 \pm 0.98^{\mathrm{ab}}$ & $17.27 \pm 0.88^{a b}$ & $16.87 \pm 0.74^{\mathrm{ab}}$ & $16.8 \pm 0.6^{\mathrm{b}}$ & $17.13 \pm 0.9^{a b}$ \\
\hline & 75 & $18.07 \pm 0.70^{c}$ & $20.33 \pm 0.91^{a}$ & $19.93 \pm 1.03^{a b}$ & $19.67 \pm 0.9^{b}$ & $19.67 \pm 0.49^{b}$ & $19.53 \pm 0.92^{b}$ & $19.80 \pm 1.01^{\mathrm{ab}}$ \\
\hline & 90 & $19.93 \pm 0.46^{b}$ & $22.87 \pm 0.74^{\mathrm{a}}$ & $22.33 \pm 0.82^{\mathrm{a}}$ & $19.87 \pm 0.92^{b}$ & $19.93 \pm 0.59^{b}$ & $19.33 \pm 0.98^{b}$ & $19.87 \pm 0.92^{b}$ \\
\hline & 105 & - & - & - & - & - & - & - \\
\hline \multirow{6}{*}{$\begin{array}{l}\text { Number of } \\
\text { flowers }\end{array}$} & 0 & - & - & - & - & - & - & - \\
\hline & $\begin{array}{l}30 \\
45\end{array}$ & $0.67 \pm 0.82^{c}$ & $2.27 \pm 0.96^{\mathrm{a}}$ & $1.40 \pm 0.83^{\mathrm{b}}$ & $1.13 \pm 0.83 \mathrm{bc}$ & $0.93 \pm 0.88^{b c}$ & $1.00 \pm \overline{-} 1.00 \mathrm{bc}$ & $0.60 \pm 0.74^{\mathrm{c}}$ \\
\hline & 60 & $2.53 \pm 1.51^{b}$ & $5.07 \pm 1.28^{a}$ & $5.00 \pm 1.00^{a}$ & $4.47 \pm 1.41^{\mathrm{a}}$ & $4.80 \pm 1.32^{\mathrm{a}}$ & $5.20 \pm 1.26^{\mathrm{a}}$ & $5.07 \pm 1.33^{a}$ \\
\hline & 75 & $6.13 \pm 1.51^{\mathrm{c}}$ & $8.13 \pm 0.83^{a}$ & $7.93 \pm 0.96^{\mathrm{ab}}$ & $6.93 \pm 2.22 b c$ & $7.53 \pm 2.00 \mathrm{bc}$ & $8.27 \pm 1.10^{\mathrm{a}}$ & $07.67 \pm 1.23^{\mathrm{ab}}$ \\
\hline & 90 & $8.07 \pm 0.96^{\mathrm{a}}$ & $8.00 \pm 1.77^{\mathrm{a}}$ & $8.60 \pm 2.20^{\mathrm{a}}$ & $9.47 \pm 2.70^{\mathrm{a}}$ & $8.93 \pm 2.49^{\mathrm{a}}$ & $8.87 \pm 2.10^{\mathrm{a}}$ & $8.40 \pm 2.06^{\mathrm{a}}$ \\
\hline & 105 & $5.60 \pm 1.12^{\mathrm{ab}}$ & $5.27 \pm 2.28^{a b}$ & $6.67 \pm 2.25^{\mathrm{a}}$ & $4.60 \pm 2.85^{\mathrm{c}}$ & $6.40 \pm 2.67^{\mathrm{ab}}$ & $6.33 \pm 2.29^{a b}$ & $6.27 \pm 3.01^{\mathrm{ab}}$ \\
\hline \multirow{7}{*}{$\begin{array}{c}\text { Number of flower } \\
\text { buds }\end{array}$} & 0 & - & - & - & - & - & - & - \\
\hline & 15 & $\begin{array}{l}- \\
-\end{array}$ & $\begin{array}{l}- \\
-\end{array}$ & $\begin{array}{l}- \\
-\end{array}$ & - & - & - & - \\
\hline & $\begin{array}{l}30 \\
45\end{array}$ & - & - & - & $1.25 \mp 0.5 \mathrm{a}$ & - & - & - \\
\hline & 60 & $0.00 \pm 0.00 \mathrm{~b}$ & $1.50 \pm 0.58^{\mathrm{ab}}$ & $1.25 \pm 0.50 \mathrm{ab}$ & $0.53 \pm 0.64^{a}$ & $0.47 \pm 0.52^{\mathrm{a}}$ & $0.47 \pm 0.64^{\mathrm{a}}$ & $0.40 \pm 0.50 \mathrm{ab}$ \\
\hline & 75 & $0.53 \pm 0.74^{b}$ & $2.20 \pm 1.42^{\mathrm{a}}$ & $1.80 \pm 1.01^{\mathrm{a}}$ & $1.73 \pm 0.88^{\mathrm{a}}$ & $1.87 \pm 1.19^{\mathrm{a}}$ & $2.13 \pm 1.25^{\mathrm{a}}$ & $1.80 \pm 1.01^{\mathrm{a}}$ \\
\hline & 90 & $3.07 \pm 0.70^{\mathrm{c}}$ & $6.93 \pm 0.59^{a b}$ & $7.33 \pm 1.05^{\mathrm{a}}$ & $6.20 \pm 1.97^{b}$ & $6.80 \pm 1.08^{b}$ & $7.53 \pm 1.25^{a}$ & $7.67 \pm 1.23^{a}$ \\
\hline & 105 & $7.40 \pm 0.90^{\mathrm{a}}$ & $7.27 \pm 1.98^{\mathrm{a}}$ & $7.67 \pm 1.76^{\mathrm{a}}$ & $6.87 \pm 2.13^{a}$ & $8.60 \pm 2.2^{\mathrm{a}}$ & $7.07 \pm 1.58^{\mathrm{a}}$ & $6.80 \pm 2.01^{a}$ \\
\hline
\end{tabular}




\subsection{Effect of PPEs on Fruit Yield Parameters}

At 115 DAT, tomato fruits were harvested manually every week from April until the end of May. A total of six harvests was carried out. Figure 1 shows the yield parameters of tomato plants subjected to different treatments of seaweed PEEs compared with untreated control plants. Figure 1A clearly showed that the application of all PEEs derived from U. rigida, C. tomentosum, G. crinale, F. spiralis, S. dubyi, and B. bifurcata significantly affected the yield of tomato plants, which increased by $26 \%, 24 \%, 33 \%, 47 \%, 90 \%$, and $34 \%$, respectively, compared to untreated plants. In addition, the number of fruits significantly improved in all PEE-treated plants. Other parameters such as the average diameter and average weight of fruits were also enhanced by PEEs application. The highest mean fruit diameters $(33.90 \pm 4.47$ and $38.94 \pm 3.79 \mathrm{~cm})$ were recorded in plants treated with PEEs derived from G. crinale and $S$. dubyi, respectively. The mean diameter of control fruits was $27.39 \pm 2.86(\mathrm{~cm})$. The mean fruit weight also significantly increased in plants treated with PEEs derived from $U$. rigida, F. spiralis, and S. dubyi, which were recorded as $31.78 \pm 8.79$, $30.74 \pm 4.16$, and $36.49 \pm 6.84(\mathrm{~g})$, respectively.
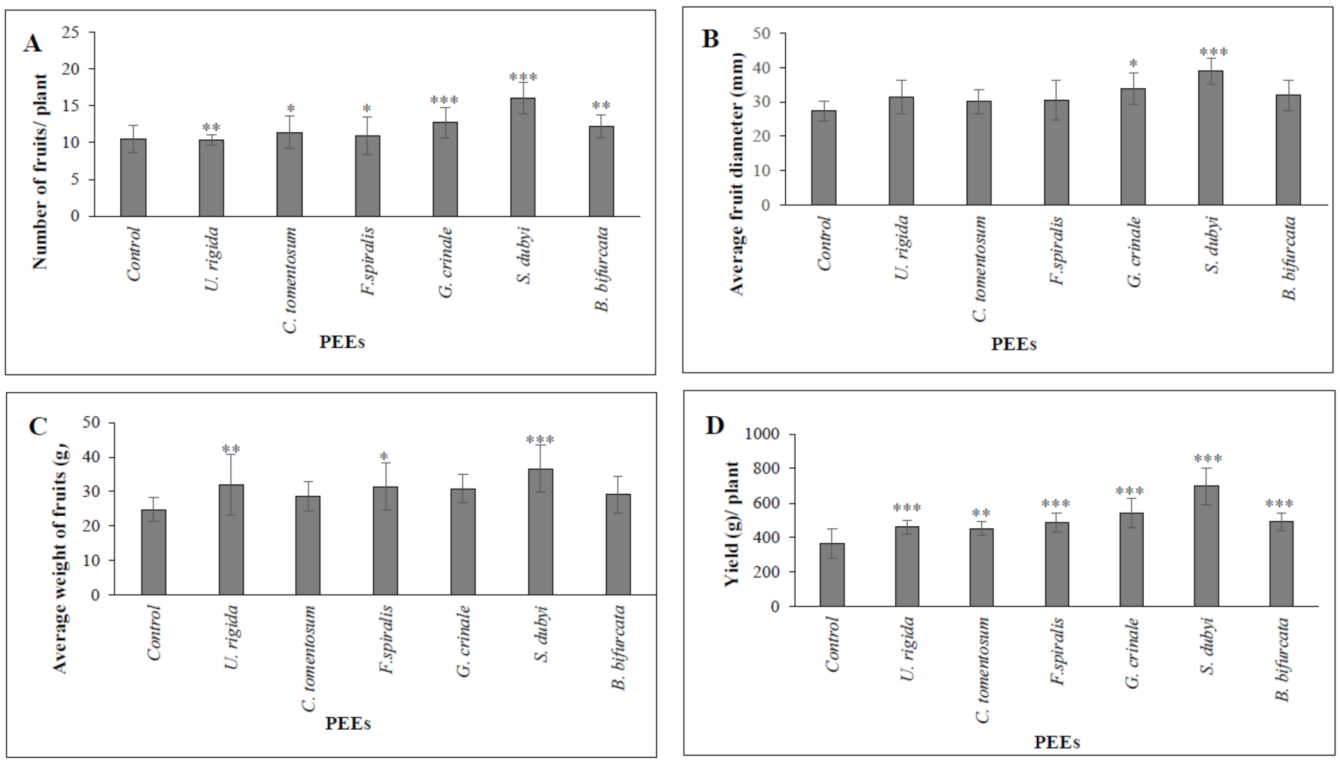

Figure 1. Fruit yield parameters of greenhouse-grown tomato plants treated 4 times (1 application after transplantation, 2 applications during the vegetative phase of growth, and 1 last application during the reproduction phase) with PEEs treatments. (A) Number of fruits per plant; (B) average of fruit diameter (mm); (C) average fruit weight (g); (D) yield of accumulated fruits per plant). The data represent the mean values of 15 repetitions with standard deviations indicated by vertical bars. * Significant difference compared to the control treatment by ANOVA analysis $(p \leq 0.05)$ *** $=p \leq 0.001 ; * *=0 \leq 0.01{ }^{*}=p \leq 0.05$.

\subsection{Effect of PPEs on Fruit Quality Parameters}

Fruit quality parameters were analyzed in red-matured tomato fruits at MAScIR Green Biotechnology laboratory after each harvest. The total soluble solids (TSS) indicating the sugar content, titratable acidity (TTA), and lycopene content of the fruits were analyzed. The obtained results represent the mean values of data recorded from the six harvests (Figure 2). As shown in the figures, the application of PEEs at various concentrations significantly affected all the studied quality parameters of tomato fruits. The highest increase in maturity index (ratio of total soluble solids and titratable acidity) and lycopene content ( $80 \%$ and $33 \%$, respectively) was obtained in fruits of tomato plants treated with S. dubyi PEEs compared with the control. 

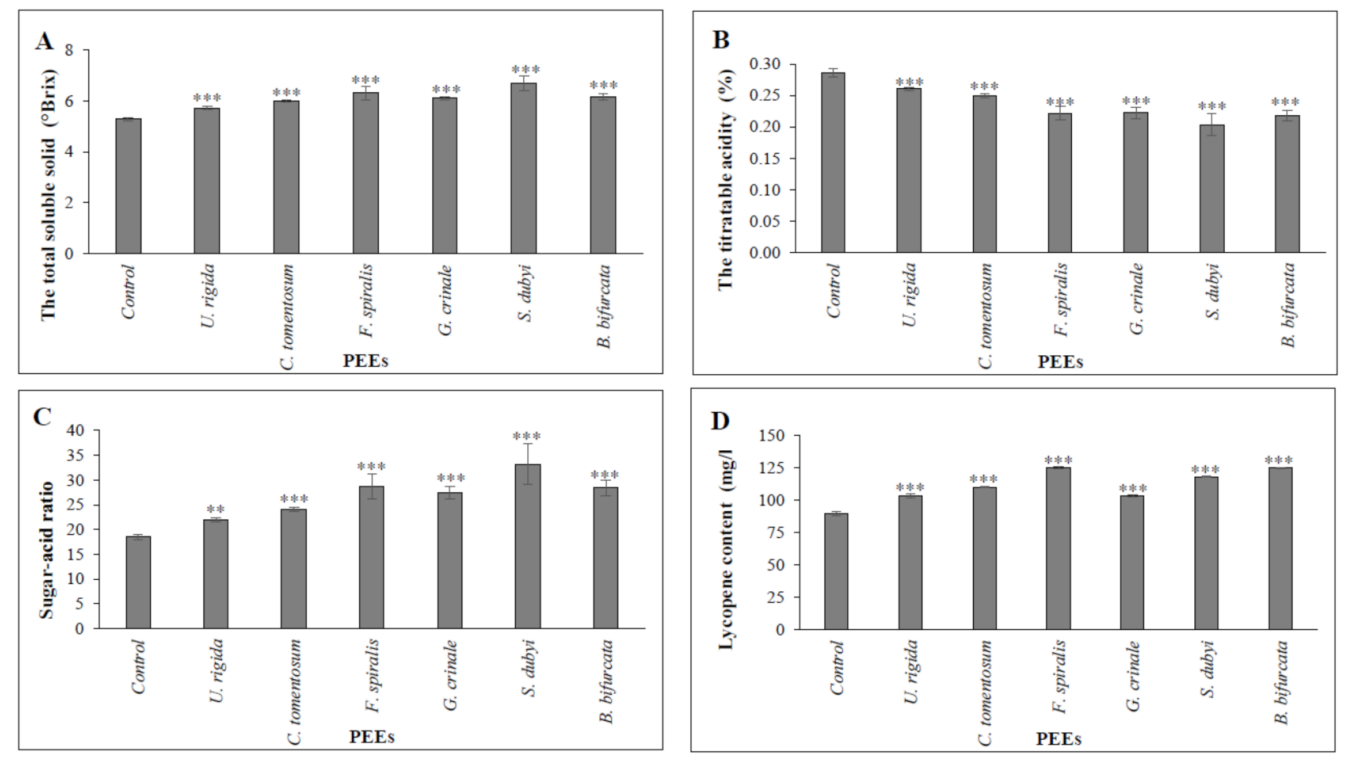

Figure 2. Quality parameters of fruits harvested from tomato plants treated 4 times (1 application after transplantation, 2 applications during the vegetative phase of growth, and 1 last application during the reproduction phase) with PEEs treatments and untreated control plants. (A) Total soluble solid content expressed in Brix degree. (B) Titratable acidity (\% citric acid). (C) Sugar-acid ratio. (D) Lycopene content. The data represent the mean values of 6 repetitions with standard deviations indicated by vertical bars. * Significant difference compared to the control treatment by ANOVA analysis $(p \leq 0.05){ }^{* * *}=p \leq 0.001 ;{ }^{* *}=p \leq 0.01$.

\section{Discussion}

The PEEs extracted from six Moroccan seaweeds have been previously assessed for their positive effect on tomato seed germination and vegetative growth either by soil or foliar applications [33,34]. In this study, PEEs' effect on tomato fruit yield and quality attributes was investigated. Results of the present study demonstrated that all 6 PEEs treatments had significant positive effects on the vegetative, reproductive, yield, and quality parameters of tomato plants cultivated under greenhouse ambient conditions.

Improved vegetative and reproductive growth of tomato plants suggests that PEEs contain common molecules or functional compounds that activate the signaling mechanism of tomato plants to increase the uptake and use efficiency of available nutrients for productive functions. A study by Sarfaraz et al. (2011) indicated that oligo alginates in brown algae induced the basal synthesis and metabolism of nitrogen assimilation in plants [37]. Brown algae-derived oligo-carrageenans also exhibited modulating effects on nitrogen assimilation and basal metabolism $[23,38]$. Furthermore, it has been reported that polysaccharides are rich in functional groups having the ability to bind to microelements with important plant nutritional values [39]. Results obtained in this study are similar to the findings recorded by Ahmed and Fahmy (2019) [40], who demonstrated the significant positive effects of natural polysaccharides (cellulose and starch) on tomato growth parameters. These effects were explained by the fact that polysaccharides can increase the water holding capacity of the soil and subsequently improve plant growth.

The significant increase in fruit yield observed in our study was likely due to a combination of factors, including an overall increase in vegetative and reproductive growth. PEEs obtained from $S$. dubyi exhibited the highest effects on all yield parameters. Chemical characterization of this extract based on FTIR analysis and monosaccharide constitution (data under publication) revealed that $S$. dubyi polysaccharides are sulfated heteropolysaccharides containing glucurono-galactan with galactose and glucuronic acid as the main extract components. Such components are commonly characterized in algal polysaccharides and could be responsible for the observed plant biostimulation effect $[41,42]$. 
The positive impact of the PEEs on tomato fruit quality was expressed by the improvement of total soluble solid, sugar-acid ratio as well as lycopene content with the application of all the PEEs. The increase in TSS by the application of PEEs can be explained by the improvement of metabolic activities leading to the synthesis of significant amounts of acids, metabolites, and glucose, which may have been the original composition of TSS [43]. Soluble sugars and organic acids are the major components of soluble solids. These components and their interaction are important for tomato quality and for processed concentrate as they affect sweetness, sourness, and flavor intensity [35]. On the other hand, lycopene, which increased in all PEEs treatments, is a pigment mainly responsible for the characteristic deep-red color of ripe tomato fruits and tomato products; such an aspect is of great economic importance [44]. A similar increase in lycopene content was observed in tomato plants treated with natural polysaccharides (cellulose, starch) [40]. Moreover, improved growth, yield, and fruit quality in PEE-treated plants can also be explained by the PEE content of sulfate groups $\left(\mathrm{SO}_{4}\right)$ and carbohydrates. The principal component analysis presented in Figure 3 showed a clear separation between treated plants and the control. The PCA clustered two correlating variables. Sugar and protein content of PEEs was closely associated with reproductive growth parameters, including flower number and flower buds, whereas the sulfate content $\left(\mathrm{SO}_{4}\right)$ of the extracts was closely associated with yield and quality attributes, including maturity index, TSS, lycopene, and plant yield. Interestingly, the seaweeds were also separated into these two clusters. Sd and Fs positively correlated with the yield and quality attributes, while Gc and Bb correlated with the plants' reproductive growth parameters.

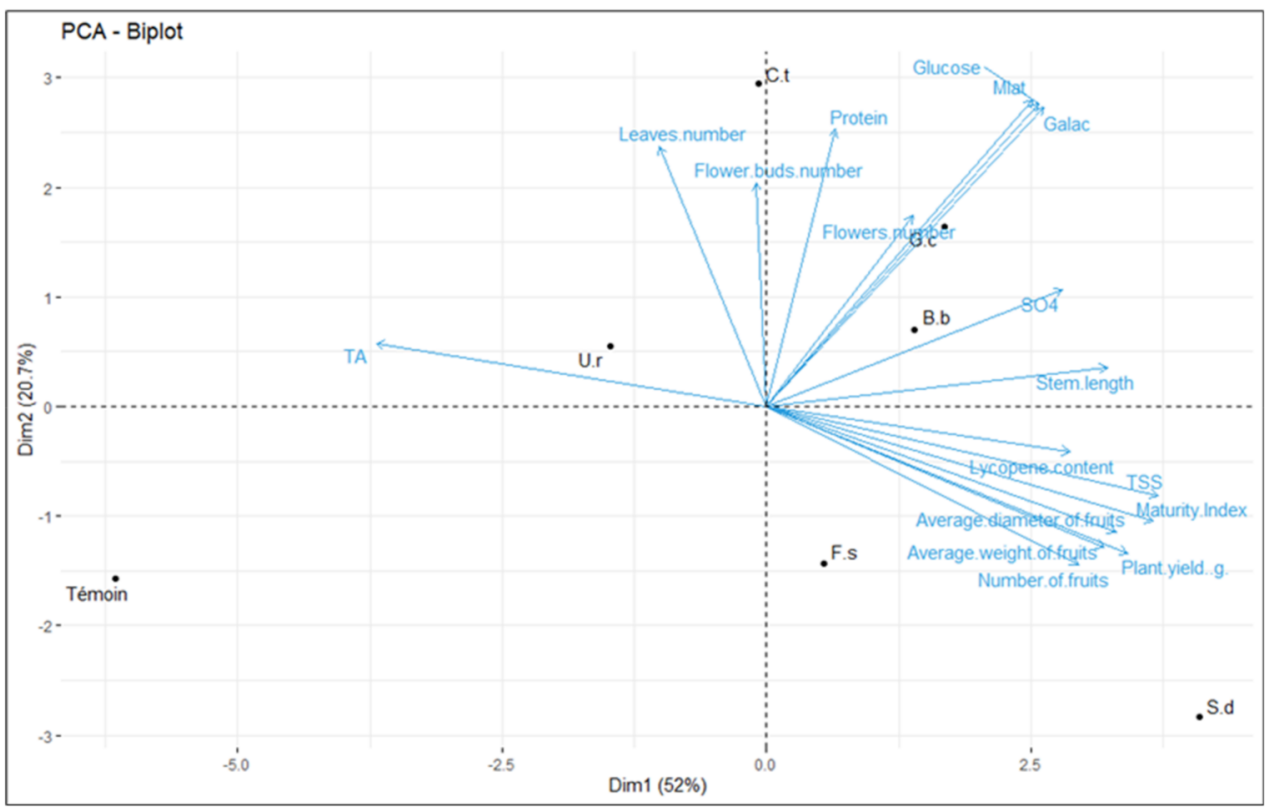

Figure 3. Principal component analysis between the following variables: glucose, maltose, galactose, protein, and sulfate $\mathrm{SO} 4$ content, plant growth parameters (leaves number, stem length, flowers numbers, and flower buds numbers), plant yield parameters (plant yield, average weight and diameter of fruits, and number of fruits) and fruit quality parameters (total Sec-soluble TSS, maturity index, and lycopene content).

PEEs obtained from G. crinale, S. dubyi, F. spiralis, and B. bifurcata exhibited the best effects, inducing significant improvement in plant yield and fruit organoleptic parameters. These results indicate the possibility of combining PEEs derived from these seaweeds.

\section{Conclusions}

Based on the greenhouse experiment, our results indicated that the application of PEEs extracted from seaweeds would be beneficial for the improvement of vegetative and 
reproductive parameters, including early flowering, fruit set precocity, yield, and quality of tomato plants and fruits. Additional collaborations are now required between crop farmers, algae farmers, researchers, and governmental entities in order to develop environmentally friendly biostimulant products in the organic market.

Author Contributions: Conceptualization, M.K., Y.F. and R.B.; Data curation, A.M. and A.A.; Formal analysis, A.M.; Investigation, A.M., I.M.K., A.B. and A.D.; Methodology, A.M., A.A., I.M.K., A.B. and A.D.; Validation, A.M., I.M.K., A.B. and A.D.; Investigation, A.M., A.A., I.M.K., A.B. and A.D.; Software, A.M.; Supervision, I.M.K., A.B. and A.D.; Validation, A.M., I.M.K., A.B. and A.D.; Visualization, A.A., I.M.K., A.B. and A.D; Writing—original draft preparation, A.M.; Writing-review and editing, A.M., A.A., I.M.K., A.B. and A.D. All authors have read and agreed to the published version of the manuscript.

Funding: This research was funded by OCP Group (AS2016), and the APC was funded by the MAScIR Foundation.

Acknowledgments: Special thanks and acknowledgments to the research and development direction of the OCP Group for their scientific and technical contribution and for supporting the funding of this study. The authors gratefully acknowledge the members of the Green Biotechnology laboratory in MAScIR Foundation for their support during the accomplishment of experiments, especially Salah Eddine Azaroual and Najib Elmernissi. Huge thanks to Chanda Mutale Joan for her valuable comments on the manuscript and Yassin Kasmi for the statistical analysis.

Conflicts of Interest: The authors declare no conflict of interest.

\section{References}

1. Desa, U. United nations department of economic and social affairs, population division. In World Population Prospects: The 2015 Revision, Key Findings and Advance Tables; Online Edition; UN DESA: New York, NY, USA, 2015.

2. Van Ittersum, M.K.; van Bussel, L.G.J.; Wolf, J.; Grassini, P.; van Wart, J.; Guilpart, N.; Claessens, L.; Groot, H.; Wiebe, K.; MasonD'Croz, D.; et al. Can sub-Saharan Africa feed itself? Proc. Natl. Acad. Sci. USA 2016, 113, 14964-14969. [CrossRef] [PubMed]

3. Batt, P.J. Fulfilling customer needs in agribusiness supply chains. Acta Hortic. 2006, 699, 83-89. [CrossRef]

4. Kyriacou, M.C.; Rouphael, Y.; Di Gioia, F.; Kyratzis, A.; Serio, F.; Renna, M.; De Pascale, S.; Santamaria, P. Micro-scale vegetable production and the rise of microgreens. Trends Food Sci. Technol. 2016, 57, 103-115. [CrossRef]

5. Bisbis, M.B.; Gruda, N.; Blanke, M. Potential impacts of climate change on vegetable production and product quality-A review. J. Clean. Prod. 2018, 170, 1602-1620. [CrossRef]

6. Sebilo, M.; Mayer, B.; Nicolardot, B.; Pinay, G.; Mariotti, A. Long-term fate of nitrate fertilizer in agricultural soils. Proc. Natl. Acad. Sci. USA 2013, 110, 18185-18189. [CrossRef] [PubMed]

7. Mengistie, B.T.; Mol, A.P.J.; Oosterveer, P. Pesticide use practices among smallholder vegetable farmers in Ethiopian Central Rift Valley. Environ. Dev. Sustain. 2017, 19, 301-324. [CrossRef]

8. Rouphael, Y.; Colla, G. Synergistic biostimulatory action: Designing the next generation of plant biostimulants for sustainable agriculture. Front. Plant Sci. 2018, 9, 1655. [CrossRef] [PubMed]

9. Drobek, M.; Frac, M.; Cybulska, J. Plant Biostimulants: Importance of the Quality and Yield of Horticultural Crops and the Improvement of Plant Tolerance to Abiotic Stress-A Review. Agronomy 2019, 9, 335. [CrossRef]

10. EBIC. The European Biostimulant Industry Council. Available online: www.biostimulants.eu (accessed on 15 April 2020).

11. Du Jardin, P. Plant biostimulants: Definition, concept, main categories and regulation. Sci. Hortic. 2015, 196, 3-14. [CrossRef]

12. Yakhin, O.I.; Lubyanov, A.A.; Yakhin, I.A.; Brown, P.H. Biostimulants in plant science: A global perspective. Front. Plant Sci. 2017, 7, 2049. [CrossRef]

13. González-González, M.F.; Ocampo-Alvarez, H.; Santacruz-Ruvalcaba, F.; Sánchez-Hernández, C.V.; Casarrubias-Castillo, K.; Becerril-Espinosa, A.; Hernández-Herrera, R.M. Physiological, ecological, and biochemical implications in tomato plants of two plant biostimulants: Arbuscular mycorrhizal fungi and seaweed extract. Front. Plant Sci. 2020, 11, 999. [CrossRef]

14. Zodape, S.T.; Gupta, A.; Bhandari, S.C.; Rawat, U.S.; Chaudhary, D.R.; Eswaran, K.; Chikara, J. Foliar Application of Seaweed Sap as Biostimulant for Enhancement of Yield and Quality of Tomato (Lycopersicon esculentum Mill.); NISCAIR-CSIR: New Delhi, India, 2011.

15. Haider, M.W.; Ayyub, C.M.; Pervez, M.A.; Asad, H.U.; Manan, A.; Raza, S.A.; Ashraf, I. Impact of foliar application of seaweed extract on growth, yield and quality of potato (Solanum tuberosum L.). Soil Environ. 2012, 31, 2.

16. Li, Y.; Mattson, N.S. Effects of seaweed extract application rate and method on post-production life of petunia and tomato transplants. Hort Technol. 2015, 25, 505-510. [CrossRef]

17. Ali, N.; Farrell, A.; Ramsubhag, A.; Jayaraman, J. The effect of Ascophyllum nodosum extract on the growth, yield and fruit quality of tomato grown under tropical conditions. J. Appl. Phycol. 2016, 28, 1353-1362. [CrossRef]

18. Murtic, S.; Oljaca, R.; Murtic, M.S.; Vranac, A.; Koleska, I.; Karic, L. Effects of seaweed extract on the growth, yield and quality of cherry tomato under different growth conditions. Acta Agric. Slov. 2018, 111, 315-325. [CrossRef] 
19. Bharath, B.; Nirmalraj, S.; Mahendrakumar, M.; Perinbam, K. Biofertilizing efficiency of Sargassum polycystum extract on growth and biochemical composition of Vigna radiate and Vigna mungo. Asian Pac. J. Reprod. 2018, 7, 27-32. [CrossRef]

20. Layek, J.; Das, A.; Idapuganti, R.G.; Sarka, D.; Ghosh, A.; Zodape, S.T.; Lal, R.; Yadav, G.S.; Panwar, A.S.; Ngachan, S.; et al. Seaweed extract as organic bio-stimulant improves productivity and quality of rice in eastern Himalayas. J. Appl. Phycol. 2018, 30, 547-558. [CrossRef]

21. Ben Salah, I.; Aghrouss, S.; Douira, A.; Aissam, S.; El Alaoui-Talibi, Z.; Filali-Maltouf, A.; El Modafar, C. Seaweed polysaccharides as bio-elicitors of natural defenses in olive trees against verticillium wilt of olive. J. Plant Interact. 2018, 13, 248-255. [CrossRef]

22. Khan, Z.H.; Khan, M.M.A.; Aftab, T.; Idrees, M.; Naeem, M. Influence of alginate oligosaccharides on growth, yield and alkaloid production of opium poppy (Papaver somniferum L.). Front. Agric. China 2011, 5, 122-127. [CrossRef]

23. Bi, F.; Iqbal, S.; Arman, M.; Ali, A.; Mahmood-ul, H. Carrageenan as an elicitor of induced secondary metabolites and its efects on various growth characters of chickpea and maize plants. J. Saudi Chem. Soc. 2011, 15, 269-273. [CrossRef]

24. González, A.; Castro, J.; Vera, J.; Moenne, A. Seaweed oligosaccharides stimulate plant growth by enhancing carbon and nitrogen assimilation, basal metabolism, and cell division. J. Plant Growth Regul. 2013, 32, 443-448. [CrossRef]

25. Maningas, J.A.C.; Castillo, K.M.D.; Grospe, F.S.; Juliano, M.J.; Abad, L.V. Effect of Foliar application of radiation modified carrageenan on the yield of rice. PNRI Newsl. 2016, 12, 5.

26. Factfish World Statistics and Data Research. Available online: www.factfish.com (accessed on 20 March 2020).

27. Oerke, C.; Dehne, W.; Schönbeck, F.; Weber, A. Crop Production and Crop Protection: Estimated Losses in Major Food and Cash Crops; Elsevier: Amsterdam, The Netherlands, 2012.

28. Arah, I.K. An overview of post-harvest challenges facing tomato production in Africa. In Proceedings of the African Studies Association of Australasia and the Pacific (AFSAAP) 37th Annual Conference Africa: Diversity and Development, Dunedin, New Zealand; 2015; pp. 1-21.

29. FAO. How to feed the world. In Global Agriculture towards 2050; FAO: Roman, Italy, 2009.

30. Tan, H.; Thomas-Ahner, J.M.; Grainger, E.M.; Wan, L.; Francis, D.M.; Schwartz, S.J.; Erdman JWClinton, S.K. Tomato-basedfood products for prostate cancer prevention: What have we learned? Cancer Metast. Rev. 2010, 29, 553-568. [CrossRef] [PubMed]

31. Dias, J.S. Nutritional quality and health benefits of vegetables: A review. Food Nutr. Sci. 2012, 3, 1354. [CrossRef]

32. Farneti, B. Tomato Quality: From the Field to the Consumer: Interactions between Genotype, Cultivation and Postharvest Conditions; Wageningen University: Wageningen, The Netherlands, 2014.

33. Mzibra, A.; Aasfar, A.; Benhima, R.; Khouloud, M.; Boulif, R.; Douira, A.; Bamouh AKadmiri, I.M. Biostimulants derived from moroccan seaweeds: Seed germination metabolomics and growth promotion of tomato plant. J. Plant Growth Regul. 2020, 40, 353-370. [CrossRef]

34. Mzibra, A.; Aasfar, A.; El Arroussi, H.; Khouloud, M.; Dhiba, D.; Kadmiri, I.M.; Bamouh, A. Polysaccharides extracted from Moroccan seaweed: A promising source of tomato plant growth promoters. J. Appl. Phycol. 2018, 30, 2953-2962. [CrossRef]

35. Tigist, M.; Workneh, T.S.; Woldetsadik, K. Effects of variety on the quality of tomato stored under ambient conditions. J. Food Sci. Technol. 2013, 50, 477-486. [CrossRef]

36. Suwanaruang, T. Analyzing lycopene content in fruits. Agric. Agric. Sci. Procedia 2016, 11, 46-48. [CrossRef]

37. Sarfaraz, A.; Naeem, M.; Nasir, S. An evaluation of the efects of irradiated sodium alginate on the growth, physiological activities and essential oil production of fennel (Foeniculum vulgare Mill.). J. Med. Plants Res. 2011, 5, 15-21.

38. Vera, J.; Castro, J.; Contreras, R.A.; Gonzalez, A.; Moenne, A. Oligocarrageenans induced a long-term and broad-range protection against pathogens and the reversion of infections in tobacco plants (var. Xanthi). Physiol. Mol. Plant Pathol. 2012, 79, 3139. [CrossRef]

39. Kaplan, D.; Christiaen, D.; Arad, S.M. Chelating properties of extracellular polysaccharides from Chlorella spp. Appl. Environ. Microbiol. 1987, 53, 2953-2956. [CrossRef]

40. Ahmed, S.; Fahmy, A. Applications of Natural Polysaccharide Polymers to Overcome Water Scarcity on the Yield and Quality of Tomato Fruits. J. Soil Sci. Agric. Eng. 2019, 10, 199-208. [CrossRef]

41. San, P.T.; Khanh, C.M.; Khanh, H.H.N.; Khoa, T.A.; Hoang, N.; Nhung, L.T.; Trinh, N.T.K.; Nguyen, T.-D. k-Oligocarrageenan Promoting Growth of Hybrid Maize: Influence of Molecular Weight. Molecules 2020, 25, 3825. [CrossRef]

42. Zou, P.; Lu, X.; Zhao, H.; Yuan, Y.; Meng, L.; Zhang, C.; Li, Y. Polysaccharides derived from the brown algae Lessonia nigrescens enhance salt stress tolerance to wheat seedlings by enhancing the antioxidant system and modulating intracellular ion concentration. Front. Plant Sci. 2019, 10, 482019. [CrossRef]

43. Sendur Kumaran, S. Effect of hydrophilic polymers on yield and quality of tomato. Int. J. Appl. Pure Sci. Agric. 2016, 2, 56-60.

44. Walallawita, U.S.; Wolber, F.M.; Ziv-Gal, A.; Kruger, M.C.; Heyes, J.A. Potential Role of Lycopene in the Prevention of Postmenopausal Bone Loss: Evidence from Molecular to Clinical Studies. Int. J. Mol. Sci. 2020, 21, 7119. [CrossRef] 